\title{
Prepucial Epstein pearls on the tip of penis
}

\author{
Gurinder Kumar 주, David Roberts
}

Department of Paediatrics, Case Western Reserve University Hospital, Cleveland, Ohio, USA

\section{Correspondence to}

Dr Gurinder Kumar;

kumargurinder@gmail.com

Accepted 21 November 2020

\section{DESCRIPTION}

A term male healthy neonate born at 39 weeks of gestation via scheduled C-section to a 31-year-old G5P5 mother with adequate prenatal care and significant prenatal history of sickle cell trait, obesity and thrombocytopaenia. All the initial infection screening including HIV/Hepatitis B,C/ Syphilis/GBS/Gonococcal/Chlamydia was negative. There was no maternal history of sexually transmitted infections. Baby was born with birth weight of $3.6 \mathrm{~kg}$, head circumference of $36 \mathrm{~cm}$ and length of $50 \mathrm{~cm}$. The clinical examination of baby was unremarkable except for a cerulean mark on the back and lesion on the tip of penis was noted as shown in figures 1 and 2. Evaluation of the external genitalia showed small, white, pearly lesions at the tip of the foreskin that were partially obscuring the urethral meatus. No spontaneous drainage was noted from the lesions. The infant was voiding without difficulty and feeding well at the breast. There were no similar lesions noted on the rest of the body or mucosal surfaces.

The differential diagnosis of pearly lesions on the penile tip could be:

1. Preputial Epstein pearls: small pearly white to yellow papules that contain keratin, similar to Epstein pearls found on a newborn's palate. The incidence of preputial pearls has been reported to be 7.3 per 1000 live-born male neonates among Indian children. ${ }^{1}$ It is a benign condition that occurs due to accumulation of keratinised epithelial cells during fetal development.

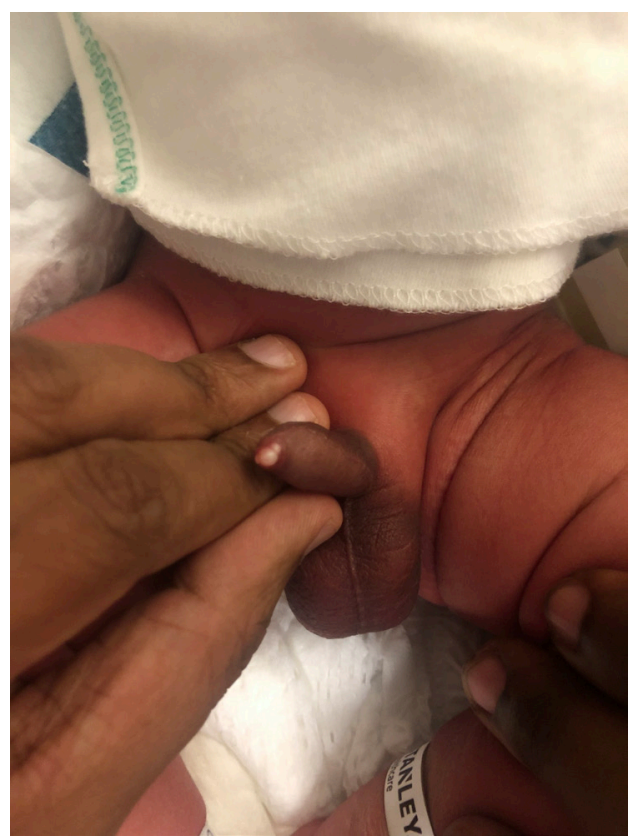

Figure 1 Lesion at the tip of penis of newborn.

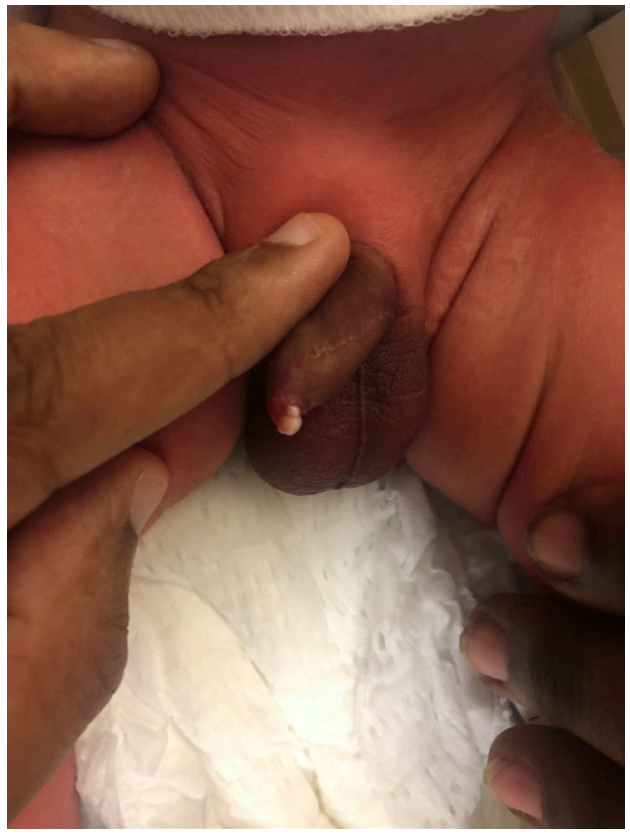

Figure 2 View of lesion at the tip of penis.

2. Smegma pearls: these are seen in uncircumcised children where it presents as a painless single or whitish yellow pearly nodule over the glans. It occurs due to collection of smegma between the base of glans and attachment of preputial membrane with the glans. It is usually seen in older children.

3. Preputial cysts: preputial cysts are located under the glans and presents as a nodular swelling. It occurs due to collection of dead skin.

4. Median raphe cyst: this presents as a solitary mobile nodule at the ventral surface of the penis formed due to tissue trapping during the development of urethral folds. The location of this lesion helps to differentiate from preputial Epstein pearls. ${ }^{2}$

Preputial Epstein pearls are formed due to plugging of the pilosebaceous or eccrine ducts and contain keratin-like substance. Penile pearls spontaneously exfoliate, and management is mainly reassurance. Our index child was circumcised the following day, and the penile pearls were removed along with the foreskin. It was not sent for histopathological examination.

Preputial Epstein pearls can be a potential source of lot of concern and anxiety to the parents. Paediatricians who are unaware of this benign condition may overtreat it with unnecessary investigations, puncturing, antibiotics and so on. It is important to counsel the family that this is a self-resolving physiological condition requiring no intervention. ${ }^{3}$ 


\section{Learning points}

Preputial Epstein pearls are a benign finding in newborn and does not need further investigation.

- Reassurance to parents is vital to avoid unnecessary anxiety.

Contributors GK and DR managed the patient. GK drafted the manuscript, and DR critiqued the final draft. DR will act as guarantor of the manuscript.

Funding The authors have not declared a specific grant for this research from any funding agency in the public, commercial or not-for-profit sectors.
Competing interests None declared.

Patient consent for publication Parental/guardian consent obtained.

Provenance and peer review Not commissioned; externally peer reviewed.

\section{ORCID iD}

Gurinder Kumar http://orcid.org/0000-0001-5457-1827

\section{REFERENCES}

1 Faridi MM, Adhami S. Prepucial Epstein pearls. Indian J Pediatr 1989;56:653-5.

2 Singh R, Faridi MM, Singh K. Prepucial Epstein pearl revisited. Trop Doct 1998:28:124.

3 Faridi MMA, Sharma A. Managing pearly prepuce- communication and masterly inaction. Indian J Child Health 2017;04:107-9.

Copyright 2020 BMJ Publishing Group. All rights reserved. For permission to reuse any of this content visit https://www.bmj.com/company/products-services/rights-and-licensing/permissions/

BMJ Case Report Fellows may re-use this article for personal use and teaching without any further permission.

Become a Fellow of BMJ Case Reports today and you can:

- Submit as many cases as you like

- Enjoy fast sympathetic peer review and rapid publication of accepted articles

- Access all the published articles

Re-use any of the published material for personal use and teaching without further permission

\section{Customer Service}

If you have any further queries about your subscription, please contact our customer services team on +44 (0) 2071111105 or via email at support@bmj.com.

Visit casereports.bmj.com for more articles like this and to become a Fellow 